\title{
Research on Teaching Evaluation System in Big Data Environment
}

\author{
ZHOU Rui-ling ${ }^{1, a}$ \\ ${ }^{1}$ Department of Computer and Information Science, Hunan Institute of Technology, Hengyang \\ 421002, China \\ a56779568@qq.com
}

Keywords: Big Data of Education; Educational Evaluation; Developmental Assessment; Data Collection; Visual Analysis

\begin{abstract}
Based on the perspective of big data of education and combined with the transformation of educational evaluation activities, this paper studies the acquisition, visual analysis and presentation techniques of big data of education. The technology of big data of education has promoted the realization of data-driven decision-making in educational evaluation and provided good support for multi-party participation in educational evaluation and realization of developmental assessment of students. Tablet computers, digital pens, wearable devices and the like can digitize different types of learning data in real time to achieve the acquisition of data for the whole process of student learning so as to provide a data base for educational assessment and decision making based on data analysis and rational evidence in the field of education. It explores the evolution of social learning network of students to reveal the characteristics of educational events in the specific space and time.
\end{abstract}

\section{Introduction}

Based on the deep excavation and scientific analysis of large amounts of data, big data is seeking the implicit relationship and value behind the data so that people can shift from the speculation based on small sample data or the preference selection based on perception to the decision-making based on data analysis and rational evidence. Big data is constantly going deep into education and has a powerful impact on some "data-intensive" education businesses such as exams, learning analytics, and so forth. To improve education and teaching evaluation, the scientific and diverse evaluation criteria shall be established according to the training objectives and the concept of talent.

\section{Teaching Evaluation in Big Data Environment}

\section{A. Construction Foundation of Teaching Evaluation}

The educational quality evaluation activities involving the government, schools, parents and all sectors of society shall be carried out. Student growth records and improvement of the overall quality evaluation shall be done to explore a variety of evaluation methods to promote the development of students. Judging from the evidence provided by the data is the basic idea of positivism. The principle of development has always been the proper meaning of educational evaluation. The self-evaluation of students and the evaluation of parents are also one of the evaluation methods adopted by many schools. Modern information technology and big data play well in the education field. Educational evaluation is designed to give us a better understanding of students and to examine classrooms and teaching processes. Big data is a hot topic of technical research in recent years. It is a technical context based on cloud computing, Internet of Things, and social networks. And it provides new technical support for further development of current information technology application. 
Table 1 Summary of the Meaning and Characteristics of Big Data

\begin{tabular}{|c|c|c|c|}
\hline $\begin{array}{c}\text { Single Point of } \\
\text { View }\end{array}$ & $\begin{array}{c}\text { Multiple Point of } \\
\text { View }\end{array}$ & Multiple Point of View & Multiple Point of View \\
\hline $\begin{array}{l}\text { Large Data } \\
\text { Sets }\end{array}$ & $\begin{array}{l}\text { 3V Features } \\
\text { Volume } \\
\text { Variety } \\
\text { Velocity }\end{array}$ & $\begin{array}{l}\text { Composite Product (Multi-level) } \\
\text { System Setting Data Entity, } \\
\text { Technology, and Thinking as One }\end{array}$ & $\begin{array}{lr}\text { New Data } & \text { Processing } \\
\text { and } & \text { Analysis } \\
\text { Technologies } & \text { Include } \\
\text { File } & \text { System } \\
\text { Technology, Database } \\
\text { System Technology, } \\
\text { Indexing Technology, } \\
\text { and So Forth }\end{array}$ \\
\hline $\begin{array}{l}\text { It Has Gone } \\
\text { Beyond the } \\
\text { Ability of A } \\
\text { Typical } \\
\text { Database to } \\
\text { Acquire, Store, } \\
\text { Manage, and } \\
\text { Analyze Data }\end{array}$ & $\begin{array}{l}\text { 4V Features } \\
\text { Volume } \\
\text { Variety } \\
\text { Velocity } \\
\text { Value }\end{array}$ & $\begin{array}{l}\text { Explore the Potential Value of Data } \\
\text { in Information Technology and } \\
\text { Ways of Thinking }\end{array}$ & $\begin{array}{l}\text { A Resource and } \\
\text { Technology is Used to } \\
\text { Help Solve Problems in } \\
\text { Many Other Areas }\end{array}$ \\
\hline & & $\begin{array}{l}\text { The Hotspot of Current Technology } \\
\text { Research is a Technical Context } \\
\text { Based on Cloud Computing, } \\
\text { Internet of Things, and Social } \\
\text { Networks, Which Provides New } \\
\text { Technical Support for the Further } \\
\text { Development of Current } \\
\text { Information Technology }\end{array}$ & \\
\hline
\end{tabular}

In addition, data from different sources are difficult to integrate. Due to the collection cost and other reasons, the data obtained are lack of persistence, resulting in the fragmentation of the implicit information connection within the data. For example, the exploration of working level and classroom learning behaviors of students; and the effect analysis of reading ability on students' mathematical performance are difficult to realize. Therefore, teachers often can only deal with teaching problems based on experience. All of them have an adverse effect on understanding students scientifically and accurately, making teaching decisions and even formulating education policies. The application of big data of education provides a good solution for overcoming the deficiencies in the current educational evaluation. 
Table 2 Main Line of Big Data Evaluation in Teaching Evaluation System Design

\begin{tabular}{|c|c|c|c|}
\hline $\begin{array}{c}\text { Single Point of } \\
\text { View }\end{array}$ & $\begin{array}{l}\text { Solvable } \\
\text { Problems }\end{array}$ & Data Analysis Basics & $\begin{array}{c}\text { Big Data Technology } \\
\text { Path }\end{array}$ \\
\hline Learner & $\begin{array}{l}\text { Character } \\
\text { Recognition of } \\
\text { Learner } \\
\text { Classification of } \\
\text { Learner Group }\end{array}$ & $\begin{array}{l}\text { Cognitive Status, Style, Attitude, } \\
\text { Interactive Mode in History Learning } \\
\text { Environment, Participation } \\
\text { Performance, and Degree of Learning } \\
\text { Difficulty of Learners }\end{array}$ & $\begin{array}{l}\text { Large Data } \\
\text { Clustering, } \\
\text { Decision-making Tree } \\
\text { Analysis }\end{array}$ \\
\hline $\begin{array}{l}\text { Teaching } \\
\text { Resources }\end{array}$ & $\begin{array}{l}\text { Construction of } \\
\text { Self-learning } \\
\text { resources } \\
\text { Generation of } \\
\text { original learning } \\
\text { resources } \\
\text { Learning } \\
\text { resources sharing }\end{array}$ & $\begin{array}{l}\text { Text, Video, Audio and Other } \\
\text { Multimedia Teaching Resources, } \\
\text { Learning Resources Shared by } \\
\text { Learners, Self-generated Learning } \\
\text { Resources of Learners }\end{array}$ & $\begin{array}{l}\text { Acquisition, } \\
\text { Collection, } \\
\text { Management and } \\
\text { Analysis of Complex } \\
\text { Data Sets }\end{array}$ \\
\hline $\begin{array}{l}\text { Teaching } \\
\text { Process }\end{array}$ & $\begin{array}{lr}\text { Learning } & \text { Trend } \\
\text { Analysis } & \text { of } \\
\text { Effectivity } & \text { and } \\
\text { Real - time } \\
\text { Correction of } \\
\text { Teaching Process }\end{array}$ & $\begin{array}{l}\text { Correlation Between } \\
\text { Outcomes and Data of Learning } \\
\text { Content, Learning Resources, } \\
\text { Teaching Behavior, etc. } \\
\text { Correlation Between Difficulty and } \\
\text { Presenting Order of Learning Content } \\
\text { and Learning Outcomes of Learners } \\
\text { Correlation Between Current } \\
\text { Learning Behavior and Future } \\
\text { Learning Outcomes of Learners }\end{array}$ & $\begin{array}{l}\text { Correlation } \\
\text { Exploration } \\
\text { Complex } \\
\text { Variables } \\
\text { Construction } \\
\text { Model Interpretation } \\
\text { Data }\end{array}$ \\
\hline
\end{tabular}

\section{B. Construction Goals of Teaching Evaluation}

(1) Big data promotes data-driven teaching decision-making. Data-driven decision-making in education refers to the process of collecting, analyzing, reporting and using data for education and teaching improvement. Big data can quickly and efficiently explore the information needed from the complex big data sets that store student information and extract the variables, taking the analysis framework of "student model based on cognitive status and learning style (cs-Ls student model)" as an example by collecting and acquiring students' access to teaching resources, the duration of learning records, the data state of practice and test, and the basic information of students, and then turning into identifiable variables in the student model so as to take cognitive status, cognitive style, learning history as variables to establish a model and describe the characteristics of students. With the support of big data technology, all the data in the model can be quickly collected and processed to achieve the purpose of analyzing the characteristics of learners comprehensively before the teaching design. The learner groups are subdivided and the individual differences of students are followed to know about learning style, learning history, and cognitive status of learners, and according to the characteristics of learners, the appropriate teaching resources and teaching strategies are chosen to improve the individualization of teaching design. 
Table 3 CS-LS Student Model Data Relationship

\begin{tabular}{|c|l|}
\hline $\begin{array}{c}\text { Create } \\
\text { Variables }\end{array}$ & \multicolumn{1}{c|}{ Collected Data as Required } \\
\hline $\begin{array}{c}\text { Student } \\
\text { Description }\end{array}$ & Student Number, Name, Gender, Age, Nationality, Major, E-mail \\
\hline $\begin{array}{c}\text { Cognition } \\
\text { Status }\end{array}$ & $\begin{array}{l}\text { Student Number, Knowledge Point Number, Preparation Status, Access Status, } \\
\text { Practice Status, Test Status, Master Status }\end{array}$ \\
\hline $\begin{array}{c}\text { Cognition } \\
\text { Classification }\end{array}$ & $\begin{array}{l}\text { Student Number, Perception Type-Intuition Type, Active Type-Reflective } \\
\text { Type, Visual Type-Verbal Type, Global Type-Sequence Type }\end{array}$ \\
\hline $\begin{array}{c}\text { Learning } \\
\text { History }\end{array}$ & $\begin{array}{l}\text { Student number, Knowledge Point number, Teaching Resources Accessed, Start } \\
\text { Time of Study, End Time of Study, Number of Practice, Number of Errors }\end{array}$ \\
\hline
\end{tabular}

Table 4 Main Application Line of Big Data in the Field of Higher Education Teaching Media Development

\begin{tabular}{|c|c|c|}
\hline $\begin{array}{c}\text { Application in the Field of } \\
\text { Teaching Media } \\
\text { Development }\end{array}$ & Data Base & Technical Path \\
\hline $\begin{array}{c}\text { Open Teaching Resources } \\
\text { Personalized Electronic } \\
\text { Learning Materials } \\
\text { Personalized Adaptive } \\
\text { Learning System } \\
\text { Large-scale Online Education } \\
\text { Platform }\end{array}$ & $\begin{array}{l}\text { Teaching Resources Data } \\
\text { Interactive Data Among } \\
\text { Teachers and Students } \\
\text { Behavior Data of Learners } \\
\text { Academic Test Results } \\
\text { history Data of Learners } \\
\text { Characteristics Data of } \\
\text { Learners } \\
\text { Learning Environment } \\
\text { Data } \\
\text { Teaching Content Data } \\
\text { Teaching Evaluation Data }\end{array}$ & $\begin{array}{l}\quad \text { Data Warehouse, Data } \\
\text { Exploration, Intelligent } \\
\text { Query, Visual Analysis, } \\
\text { Learning Analysis, Online } \\
\text { Processing Analysis }\end{array}$ \\
\hline
\end{tabular}

(2) Big data promotes student developmental assessment. Education evaluation can not only measure some abilities and characteristics of students, but also evaluate the process and level of students' development and growth according to the educational goals. This is the establishment of the concept of developmental evaluation in modern education evaluation. Developmental evaluation means the process of judging students' educational activities and realizing their development goals by systematically collecting evaluation information and conducting analysis. Developmental assessment plays a major role in the evaluation and diagnosis, highlighting the process of evaluation and focusing on individual differences in students. Therefore, it is often closely integrated with the students' learning process for long-term tracking. The biggest impact of big data on the teaching evaluation system is reflected in the increased accessibility and controllability of decision-making information in the teaching process. The teaching evaluation system based on "data-management" can make teachers, students and education administrators in the teaching process get the data they need, taking the prediction of learning behaviors and learning trends based on the data, and the data analysis generated in the learning process as the basis, so as to make the decision-making conducive to the teaching process. 
Table 5 Main Line of Big Data on the Construction of Teaching Evaluation

\begin{tabular}{|c|c|c|}
\hline Main Decision-making & $\begin{array}{c}\text { Decision-making Basis for } \\
\text { Data }\end{array}$ & $\begin{array}{c}\text { Decision-making of } \\
\text { Education and Teaching }\end{array}$ \\
\hline & & $\begin{array}{c}\text { Implement Teaching } \\
\text { Intervention } \\
\text { Adjust Teaching Content } \\
\text { Teacher }\end{array}$ \\
Improve \\
education administrator of \\
learner & Data Prediction & Teaching \\
& Data Analysis & Strategies \\
& Data Correlation Exploration & Adjust Teaching Progress \\
& & Review Teaching Content \\
& & Strengthen the Number of \\
& & Tests \\
& & Rich Teaching Resources \\
\hline
\end{tabular}

(3) Big data provides ways of multi-party participation in evaluation. In the past, the evaluation of students mainly focused on students' academic proficiency testing, which was mainly completed by school-related departments and teachers. The entire evaluation system was characterized by closure. The current evaluation activities emphasize students' developmental evaluation and overall quality evaluation, which runs through the entire learning process of students and covers their learning activities and behaviors both inside and outside school. A variety of sources, different structures of the data summary will be used to analyze the overall quality of students, and through the continuous accumulation of data, so that all kinds of parameters and models can be established to improve the accuracy of the analysis. It can be seen that the big data of education emerges directly from various educational activities. Each educational stakeholder is not only the producer of educational data but also the consumer of educational data. The evaluation activity based on open big data set up a bridge for main multiple parties who can grasp and provide students with learning data in different situations to participate in evaluation activities. It can be said that data is the core factor that drives the transformation of education assessment. The study suggests that from the user's point of view, it is easy to feel the changes brought by big data from the entrance and use of data, namely the collection and analysis of data in the education evaluation activities.

\section{Big Data Provides Ways of Multi-party Participation in Evaluation}

After collecting the big data of education, we need to extract the teaching information contained in the data through data exploration and analysis technology in order to carry out the teaching evaluation. In addition to the conventional means of education statistics, multi-dimensional drill-down or scroll-up of data cubes composed of big data can be used to extract deeper knowledge needs and promote more and more data exploration technologies such as cluster analysis and association analysis to be applied to the teaching evaluation of students. Through association analysis, multi-dimensional data such as learner's personal information data, learning content data, social learning interaction data and learning device data can be associated with each other to calculate the degree of association. Maps of $\mathrm{H}$-tree, cone tree, balloon, radiogram, and hyperbolic tree are used to characterize this type of information. Assessing and revealing students' learning network connection is helpful to identify the construction and evolution of students' social learning networks and achieve a learner-centered learning approach. As shown in Fig. 1, the behavior data and user data associated with a knowledge point are collected on the platform of social learning resources so that the network connection of the knowledge point is constructed. Therefore, it can be used to assess the learning participation and contribution of different learners. 


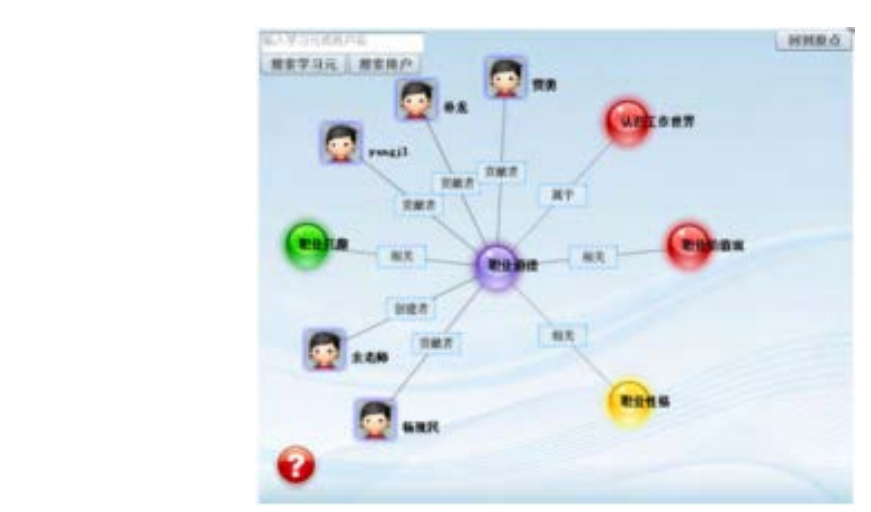

Figure 1 Knowledge-based Social Network Visualization Analysis

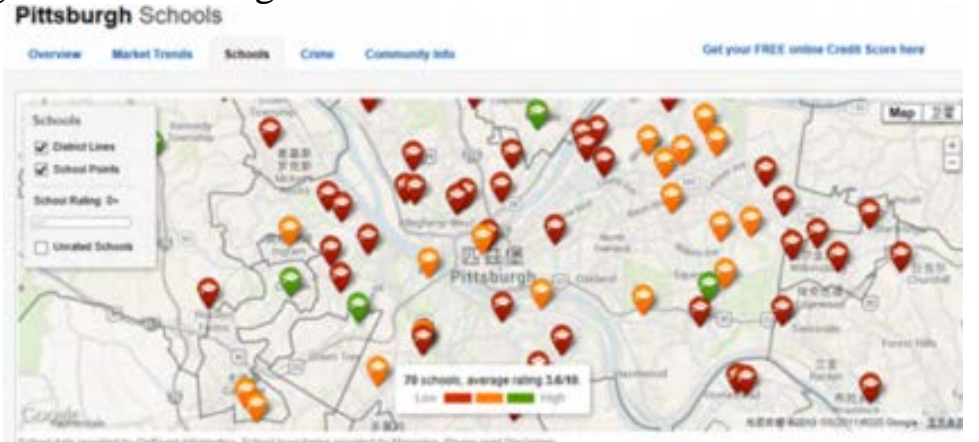

Figure 2 Visual Analysis of Education Spatial-Temporal Data

The "dynamic map" is used to turn complex data into visual images. Icons with different colors represent different statuses of schools. The green icon indicates that the school is beyond the average level, which the orange points represent, and the red parts are alert schools. This visual analysis, shown in Figure 2, visually displays the quality of education in schools in different regions and effectively supports scientific educational decisions.

\section{Conclusion}

Education is a complex system. Scientific evaluation and precise diagnostic interventions of teaching problems are challenging tasks. Big data of education preserved and collected by modern education and teaching techniques, provides a good foundation for such tasks. Strengthen the research on the new regularity of learning and education revealed in the big data of education and absorb it in the teaching evaluation, construction and verification of student learning model so as to enhance the efficiency and quality of education data exploration.

\section{References}

[1] Li Baoping, Zhou Yin. Research on Teaching Evaluation Based on Big Data [J]. Modern Education Technology, 2016,06:5-12.

[2] Li Wei. Optimization of Embedded Information Literacy Education Business Process in Big Data Environment [J]. Intelligence Information Work, 2016,03:100-106.

[3] Fu Dajie, Tang Lin. Research on the Precise Teaching Model Based on Big Data [J]. Modern Education Technology, 2017,07:12-18.

[4] Han Chengyong. College Teaching Evaluation in the Background of Big Data [J]. Computer Knowledge and Technology,2017,17:159-161+165.

[5] Hu Bicheng, Wang Zulin. The Role and Challenges of “Big Data” to Education and the Tendency of Education Reform -- A Review of the Latest Research Progress of Education Reform in the Big Data Era[J]. Modern College Education, 2015,04:98-104. 